\title{
Methodology, Speech, Society: The Hebrew Bible
}

\section{Yehoshua Gitay}

\author{
Stellenbosch: SUN MeDIA 2011 \\ Pages: $\quad 193$ \\ ISBN $\quad 978-1-920338-45-9$
}

\author{
Reviewed by Douglas Lawrie \\ Department of Religion and Theology \\ University of the Western Cape
}

\section{$\mathrm{R}$} hetorical criticism has flourished in New Testament studies, with many scholars drawing on either Vernon Robbins's socio-rhetorical approach or the tools provided by the Graeco-Roman rhetoricians. Much less has been done in the study of the Hebrew Bible, particularly if one excludes those rhetorical studies that follow the lead of James Muilenburg. Yehoshua Gitay has for decades been one of the exceptions. What lends added interest to his work is that he draws strongly on the New Rhetoric of Chaim Perlman (and Lucie Olbrechts-Tyteca) - something that few other biblical scholars do. As a result, he pays attention in his analyses to arguments (in a broad sense), persuasive potential and societal impact and not only to literary form. This is also evident in the current collections of ten essays, grouped under the headings 'Methodology', 'Speech' and 'Society'. All but one of them had previously appeared as journal articles or book chapters.

Nor is it surprising that the strongest contributions are those in which the element of rhetorical criticism predominates. In 'Biblical Rhetoric' he clarifies important basic points about the religious rhetoric of the Hebrew Bible, particularly its dialectical, dialogical nature, and points out the implications for biblical religion. In "The Role of Rhetoric in the Rise of Leadership: The Case of Judah", he deals with rhetoric at two levels. There is Judah's rhetorical performance in the text and the rhetoric of the text, which intends to show that Judah is better fitted to be a leader than Reuben. Whether or not one agrees with Gitay's holistic reading of the Joseph story, in which most critics detect at least two sources, he ably illustrates that narratives can be used and analyzed rhetorically.

This is also done in the two essays on Job, and, in a broader sense, in the essays on Genesis 2-3 and 13-14. In the essay on Job, he shows how rhetorical theory can contribute to an understanding of the Book of Job. In the essay on Genesis 13-14, he argues that when undue emphasis is placed on forms in a narrative, narrative function is sometimes forgotten. In 'History, Literature and Memory' he deals with the ways in which discourses arise as responses to others and history is formulated to reshape collective memory - another rhetorical theme.

There are many valuable insights here, not the least being that in rhetoric history (Bitzer's rhetorical situation), society and language meet and interact. For Gitay is indeed also deeply aware of the crucial role of language, as can be seen from his essays on Genesis 2-3 and Lamentations. But the limitations of rhetoric to which Gitay refers in dealing with Job also apply to the rhetorical critic. Rhetoric indeed deals in what is persuasive, not in 
assured knowledge, though I would take issue with Gitay's view (p. 156) that in rhetoric there is no search for knowledge. This also applies to rhetorical critics, who seek the most plausible interpretation of the available data but cannot claim certainty. Not everyone would find all Gitay's analyses convincing. Can we conclude from the narrative of Genesis 2-3 that at first Adam and Eve are "immortal and Eros is unknown and unfelt" (p. 62)? Then again, his account of the relationship between Haggai, Zechariah, Chronicles and Isaiah 66 is highly interesting but also highly speculative. But precisely this is the challenge of rhetorical criticism: those who criticize have to offer a more plausible alternative.

The first two essays in the collection, which do not deal with rhetoric, both leave me with ambivalent feelings. In "Literary Criticism versus Public Criticism", he deals with the problem of the "gap between scholarship and readers of the religious schools" (p. 14) and with the shift to synchronic studies and the perspective of the reader in an attempt to deal with the problem. In his discussion, Gitay raises important questions, particularly about the relationship between theory and instance and the nature of 'a book'. Few scholars would be unsympathetic to his plea that scholarship should be scholarship and should not "pander to a particular interested audience" (p. 27) and very many would agree that historical criticism of the Bible should not be abandoned simply because it "might offend sensitive readers".

Yet his conclusion raises many questions, partly because the authors he cites in support of his position make strange bedfellows. Is the distinction between the literary scholar and the public critic (p. 25f) really as clear as all that and can literary scholars ever by their use of methods establish "a science in terms of a unified structure of knowledge" (p. 19)? Those most interested in the problem he addresses may feel that he has provided food for thought rather than a solution.

In "A Call for a Paradigm Shift" he challenges the 'form-critical paradigm' in the light of studies in oral literature and culture. He argues that a paradigm shift that takes orality and oral composition seriously will, apart from doing more justice to the Hebrew Bible, transfer the centre of biblical scholarship from the West to Africa, since Africans will be able to draw on their rich oral tradition. He indicates that standard criteria for identifying breaks in a text, repetitions and shifts from prose to poetry, for instance, cannot be applied to oral literature. An oral hermeneutics that draws on comparative material from Africa may reveal a 'more unified composition' in the Pentateuch (p. 37) and may do more justice to prophetic speech (p. 38).

Promising as this sounds, I wonder whether Gitay's 'form-critical paradigm' is not partly a straw man and partly an obsolescent relic. Does anyone still believe that the Bible was composed by stitching together atomic 'pure forms', each of which originally had an oral life of its own? The issue of oral composition of sophisticated larger units was already raised by Scandinavian scholars such as Engnell; Westermann, a form critic, acknowledged that artistic poetics sayings could have an oral origin. The debate subsided, not because the theory of oral composition was completely rejected, but because no adequate criteria could be found for distinguishing between oral compositions and composite written ones emanating from an oral culture. To invoke Gitay himself, a theory of oral composition should not blind us to the peculiarities of each instance.

One might, in short, wish to start reading from the third essay and return to the first two later. Although the first section is entitled 'Methodology', one gets a better impression of Gitay's method of reading texts in the other sections. In these one notes also that in his own scholarly interpretations he does not engage only with members of his own guild - he cites authors from various fields - and that he deals with matters that would interest a wider 
readership. A rhetorical critic is also a rhetorician - one who knows how to be an audience and address an audience.

Three brief comments on technical matters: Gitay says that some of the original articles were modified slightly "in order to ensure coherence of the whole" (p. 5). Though the motive is commendable, the process has resulted in some detectable unevenness in some essays - an invitation for redaction critics. The book has a single index, which is effectively a subject index: there is no index of authors cited or of biblical passages. Finally, proof-reading is never perfect. It is, nevertheless unfortunate that some errors, minor in themselves, disconcert the readers. For instance, it takes a while to see that 'scarifying' (p. 178) should be 'sacrificing'. 